\title{
Islamic Social Reporting Of Listed Companies In Malaysia
}

Rohana Othman, Universiti Teknologi MARA, Malaysia

Azlan Md Thani, Universiti Teknologi MARA, Malaysia

\begin{abstract}
The resurgence of Islam to a loftier pedestal as a way of life opened up an additional dimension to financial reporting to stakeholders. Muslim decision-makers expect corporations to include additional information in their reports to enable them to exercise prudence, both from economics and Islamic jurisprudence point of views. Based on the Islamic theoretical foundation of social accountability and full disclosure, Muslim business owners - or in this study, the shariahapproved companies, must prove that they are operating under Islamic laws. The Islamic capital market has developed at such a rapid pace that the shariah-approved companies are beginning to present a religious aspect to their financial statements by disclosing the fulfilment of its obligations in line with the shariah, like zakat, sadaqa, wages and compensation, and the conduct of business activities within a halal environment; hence, the need for Islamic Social Reporting (ISR). This study attempted to measure the extent of ISR as practiced by shariah-approved Malaysian companies listed in Bursa Malaysia in their annual reports. The study led to a conclusion on the degree of accountability on the part of the companies by way of their conformity to shariah. Based on the descriptive statistics of the disclosure index, it can be concluded that the extent of ISR in the annual report of selected companies is considered minimal.
\end{abstract}

Keywords: Islamic Social Reporting (ISR), shariah-approved companies

\section{INTRODUCTION}

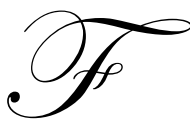

inancial reporting was used by corporations as a means of communicating information to their stakeholders, such as the individual investors, institutional investors and financial analysts. This group used the annual report as their primary influence in decision-making. In Malaysia, the Financial Reporting Standard (FRS) 101 had made it explicit to the management of corporations that additional information should be incorporated into their annual reports if that would assist their stakeholders to make better economic decisions (Zulkifli and Amran, 2006). Information is useful for decision-making when social and environmental information are provided according to the demand of the more influential users (Mohamed Zain, 1999).

Additionally, with the resurgence of Islam, Muslim decision-makers were expecting corporations to disclose more information that would help them fulfil their spiritual needs. This was because the current corporate social reporting initiatives, although they fulfilled a wider audience's needs, lacked the most pertinent items from an Islamic perspective. This may impair the judgement of Muslim decision-makers and adversely affect their spiritual being (Haniffa, 2002). Moreover, Muslim business owners needed to prove that they were operating under Islamic laws. Haniffa and Hudaib (2002) suggested that a full disclosure in the annual report of relevant and reliable information would assist the Muslim stakeholders to make both economic and religious decisions, as well as assist management in fulfilling their accountability to Allah SWT and the society.

Haniffa (2002) suggested that Islamic Social Reporting (ISR) was needed for the Muslim community with the objectives of demonstrating accountability to Allah and the community and to increase transparency of business activities by providing relevant information in conformance to the spiritual needs of the Muslim decision-makers. This study attempted to measure the extent of Islamic Social Reporting (ISR) as practiced by shariah-approved 
listed companies in their annual reports in Malaysia as they were expected to be more accountable in terms of reporting their activities in conformance with shariah (Islamic laws).

\section{LITERATURE REVIEW}

\section{Accountability}

From the Islamic perspective, the concept of accountability would be defined as a perceived relationship between individuals and firms, with God. This was an extension of the basic Islamic concept of tawhid which meant 'unity with God' (Maali et al., (2006). In Islam, all people and businesses were accountable to God and to umma (Islamic society) by recognising the rights of others. Additionally, every Muslim must strive for an optimal balance between worldly gains and spiritual rewards, which was dependent on their performance in this world (Baydoun and Wilet, 1997). This added another dimension to the valuation of things and deeds compared to those already embodied in western financial statements (Siddiqi, 1981). In corporations, the management and the shareholders were accountable for their actions to all the stakeholders of the firm or in other words to society or the public at large.

Baydoun and Willet (2000) suggested that from the perspective of corporate reporting, two essential principles underlie the concept of accountability in Islam, viz., the principle of full disclosure and the concept of social accountability. The concept of social accountability under Islam was related to the principle of full disclosure, where the preparer of accounts had to disclose everything that was believed to be 'of importance to the Islamic users for purposes of serving God'. The concept of full disclosure was thus related to the concept of accountability. Hence the key objectives of the ISR were; to show whether the organisation was compliant with Islamic principles; to show how the operations of the organisation had affected the well-being of the Islamic community; and to help Muslims perform their religious duties (Maali et. al., 2006).

\section{Islamic Social Reporting (ISR)}

With the rapid development in Islamic Capital Market, the shariah-approved companies were expected to present a religious dimension to their financial statement disclosures for the benefit of Muslim stakeholders. Haniffa and Hudaib (2001) further emphasised that the conceptual framework for Islamic accounting should be based on the shariah as it was supported by the objectives of Islamic accounting as follows:

'To assist in achieving socio-economic justice (al-falah) and recognize the fulfilment of obligation to Allah, society and individuals concerned, by parties involved in the economic activities viz. accountants, auditors, managers, owner, government, etc as a form of worship.'

They also stressed that organisations should disclose how it was fulfilling its duties and obligations according to the shariah, for example their lawful dealings, zakat to the beneficiaries, sadaqa (charities/gifts), wages, the objective of any business ventures and initiatives to protect the environment, among others. To achieve this purpose, an Islamic corporation was expected to disclose any prohibited transactions they made, zakat obligations they ought to pay and have already paid as well as their social responsibility role, among others. This meant that financial reporting in Islamic corporations was more detailed than the prevalent conventional disclosure requirements.

However from the studies conducted on the extent of Islamic information reported in the annual reports, it was discovered that they were scarce and limited, especially in Malaysia. In general, there has been a lack of empirical and systematic study on financial reporting with respect to voluntary Islamic information disclosure. Hence the information derived from this study would shed some light on how to create better accountability and transparency especially among shariah-approved listed companies. Furthermore, the findings would help better economicus-religiosus decisions (ability to make economic decisions based on shariah laws) to be made. 


\section{Research design: Content Analysis}

To measure the extent of ISR, the content analysis method was used to measure the Islamic information disclosed in the annual reports of shariah-approved listed companies. Content analysis was chosen as it was the most commonly used method to examine written material contained in annual reports (Gray et. al., 1995; Harahap, 2003; Nik Ahmad et. al., 2003; Ousama and Fatima, 2006; Thompson and Zakaria, 2004).

\section{Development of the Disclosure Index}

An extensive review of prior studies was undertaken to develop a list of relevant ISR that should be disclosed by corporations. For an item to be included, it must have been used in previous published studies. However, only a few empirical studies were found on the development and use of disclosure index with ISR specifications for non-financial institutions (Ousama and Fatima, 2006; Hassan (2006) and Muhammad, 2006). Hence the following steps were undertaken to form the basis for the development of the disclosure index for this study:

Step 1: Adoption of the Islamic Social Reports based on five themes as proposed by Haniffa (2002). There were 13 items known as the primary list. In addition to the existing themes proposed by Haniffa, this study included corporate governance as an additional theme because the literature support believe that corporate governance is critical as it can ensure companies complied with Islamic principles and have not entered into any transaction that violates the Islamic principles.

Step 2: Adding some other disclosure items from the Islamic perspective, based on the literature review from Baydoun and Willet (2000), Maali, Casson and Napier (2006), Ousama and Fatima (2006), Harahap (2003), MASB Technical Release i-1: Accounting for Zakat on Business (2006), Sulaiman and Willet (2003), Nik Ahmad, Sulaiman and Siswantoro (2003), Sulaiman (2005), Bursa Malaysia's CSR Framework for Malaysian PLCs (2006), Global Reporting Initiatives (GRI): Sustainability Reporting Guidelines, Version 3 (2006), Sustainability Reporting Guidelines for Malaysian Companies, ACCA (2005), Environmental Reporting Guidelines for Malaysian Companies, ACCA (2003), Guthrie, Petty and Ricceri (2006).

Step 3: Reviewing the disclosure requirements (mandatory disclosure) of the Companies Act 1965, Financial Reporting Act 1997, Malaysian Accounting Standards Board, Financial Reporting Standards 2006 and Malaysian Code of Corporate Governance Revised 2007; and excluding them from the primary disclosure index developed in Step 1 and 2 above

Step 4: Reviewing the index with supervisor and other academicians.

A total of 43 items of disclosure index were developed and then categorised into six themes namely; Finance and Investment, Products/Services, Employee, Society, Environment and Corporate Governance. Each theme contained several disclosure items. The nominal score was used to record the absence (represented by "0") or the presence (represented by "1") of an item which was called the un-weighted approach. This was displayed in Appendix A.

\section{Six Themes of Disclosure}

Finance and Investment

The information to be disclosed was whether the sources of finance and investment were interest-free (riba) and speculative-free (gharar) as these were strongly forbidden (haram) in Islam as mentioned in the Quran: "O ye who believe! Fear Allah; and give up what remains of your demand for usury, if ye are indeed believers." (Quran, 2:278-9) 
Products/Services

It was the responsibility of the corporations to disclose all products or services that fell into the category of haram (forbidden) such as liquor, pork, arms dealings, gambling and entertainment. Muslims were really concerned with the halal status of the products/services (Haniffa, 2002). This was supported by the following Hadith: Verily Allah and His Messenger have forbidden the sale of wine, carcass, swine and idols(HR Muslim).

Employee

The Islamic community needed to know if the company dealt justly with its employees via information such as wages, nature of work, working hours per day, annual leave, health and welfare, policies regarding religious matters such as prayer time and place, education and training support to employees, equal opportunities and the working environment. Employers were expected to be generous to their employees as stated in the Hadith: By taking work from someone without paying him his legitimate wages is equivalent to pressing a free man into slavery and to produce goods from his labours, since, when he has reaped the benefit without offering compensation, he has purchased the labourer and in effect has regarded him as a slave whom he has purchased (Bukhari).

Society

The needs of the ummah or public at large could be achieved through saddaqa (charities), waqf (trusts) and Qard hassan (lending with no profit) (Haniffa, 2002). The corporations had to disclose its role in enhancing economic development and addressing social problems for example; housing, literacy, scholarships, etc. of the societies in which they operate (Maali et al., 2006). As stated in Quran: If ye disclose (acts of) charity, even so it is well, but if ye conceal them and make them reaches those (really) in need, that is best for you (Quran, 2:271)

\section{Environment}

Corporations were not supposed to be involved in any kind of activity that might destroy or harm the environment. As such, information related to the use of resources and programmes undertaken to protect the environment should be disclosed. The Quran and Hadith condemn exploitation of the environment: Corruption has appeared on the land and sea because of what men's hands have done (Quran, 30:41).

\section{Corporate Governance}

The amendment made by the Bursa Malaysia's Listing Rules required all public listed companies to disclose a narrative statement on how they had applied the principles of corporate governance and the extent of its compliance with the Code on Corporate Governance' best practices recommendations (Bursa Malaysia, 2001). Corporations should disclose all forbidden activities such as monopolistic practice, hoarding necessary goods, price manipulation, gambling, gaming and any kind of unlawful activities (Sulaiman, 2005). This duty was emphasized in the Quran: 'and not truth with falsehood, nor conceal the truth when you know. (Quran, 2:42)

\section{SAMPLE}

The top 100 largest companies listed on the Bursa Malaysia were selected based on their market capitalization as at 14 August 2007. A review of their annual reports was done for the years 2004 till 2006 to examine the trend in the extent of the disclosure items. Only 56 companies proved to be the valid sample for this study as they were shariah approved companies and not within the finance industry.

\section{DATA ANALYSIS}

Descriptive statistics through content analysis was used to describe the presence or absence of the 43 ISR items which were coded according to the themes of the disclosures. The coding sheet used was as displayed in Appendix A. The maximum score for each of the 6 themes was 56 times multiplied with the number of ISR items for that respective theme in any year of study. The results were shown in Table 1 below. 
Table 1: The ISR Score of Disclosure According to Individual Items and Themes

\begin{tabular}{|c|c|c|c|c|}
\hline No. & Items of disclosure & $\begin{array}{l}2004 \\
\%\end{array}$ & $\begin{array}{l}2005 \\
\%\end{array}$ & $\begin{array}{l}2006 \\
\%\end{array}$ \\
\hline $\mathbf{A}$ & Finance And Investment Theme & $\mathbf{1 7 . 5 6}$ & $\mathbf{1 7 . 8 6}$ & $\mathbf{1 7 . 8 6}$ \\
\hline 1 & Riba activities & 100.00 & 100.00 & 100.00 \\
\hline 2 & Gharar & 0.00 & 0.00 & 0.00 \\
\hline 3 & Zakat: method used/amount/beneficiaries & 1.79 & 1.79 & 0.00 \\
\hline 4 & Policy on Late Repayments and Insolvent Clients/Bad Debts written-off & 0.00 & 0.00 & 0.00 \\
\hline 5 & Current Value Balance Sheet (CVBS) & 0.00 & 0.00 & 0.00 \\
\hline 6 & Value Added Statement (VAS) & 3.57 & 5.36 & 7.14 \\
\hline $\mathbf{B}$ & Products And Services Theme & 24.55 & 25.45 & 27.68 \\
\hline 7 & Green product & 10.71 & 14.29 & 12.50 \\
\hline 8 & Halal status of the product & 1.79 & 1.79 & 3.57 \\
\hline 9 & Product safety and quality & 66.07 & 67.86 & 78.57 \\
\hline 10 & $\begin{array}{l}\text { Customer complaints/incidents of non-compliance with regulation and voluntary codes } \\
\text { (if any) }\end{array}$ & 19.64 & 17.86 & 16.07 \\
\hline $\mathbf{C}$ & Employees Theme & 17.32 & 20.00 & 22.86 \\
\hline 11 & Nature of work: working hours/holidays/other benefits & 1.79 & 0.00 & 0.00 \\
\hline 12 & Education and Training/Human Capital Development & 55.36 & 62.50 & 69.64 \\
\hline 13 & Equal Opportunities & 17.86 & 23.21 & 26.79 \\
\hline 14 & Employee involvement & 37.50 & 44.64 & 41.07 \\
\hline 15 & Health and Safety & 39.29 & 44.64 & 55.36 \\
\hline 16 & Working environment & 17.86 & 21.43 & 28.57 \\
\hline 17 & $\begin{array}{l}\text { Employment of other special-interest-group (i.e. handicapped, ex-convicts, former drug- } \\
\text { addicts) }\end{array}$ & 1.79 & 3.57 & 5.36 \\
\hline 18 & $\begin{array}{l}\text { Higher echelons in the company perform the congregational prayers with lower and } \\
\text { middle level managers. }\end{array}$ & 0.00 & 0.00 & 0.00 \\
\hline 19 & $\begin{array}{l}\text { Muslim employees are allowed to perform their obligatory prayers during specific times } \\
\text { and fasting during Ramadhan on their working day. }\end{array}$ & 0.00 & 0.00 & 0.00 \\
\hline 20 & Proper place of worship for the employees. & 1.79 & 0.00 & 1.79 \\
\hline D & Society Theme & 30.03 & 32.47 & 36.04 \\
\hline 21 & Saddaqa/Donation & 48.21 & 51.79 & 62.50 \\
\hline 22 & Waqf & 5.36 & 10.71 & 12.50 \\
\hline 23 & QardHassan & 1.79 & 3.57 & 3.57 \\
\hline 24 & Employee Volunteerism & 28.57 & 32.14 & 35.71 \\
\hline 25 & Education: School Adoption Scheme/Scholarships & 46.43 & 57.14 & 66.07 \\
\hline 26 & Graduate employment & 14.29 & 14.29 & 14.29 \\
\hline 27 & Youth development & 21.43 & 16.07 & 12.50 \\
\hline 28 & Underprivileged community & 46.43 & 48.21 & 57.14 \\
\hline 29 & Children care & 28.57 & 26.79 & 28.57 \\
\hline 30 & Charities/Gifts/Social activities & 41.07 & 51.79 & 46.43 \\
\hline 31 & Sponsoring public health/recreational project/sports/cultural events & 48.21 & 44.64 & 57.14 \\
\hline $\mathbf{E}$ & Environment Theme & 15.31 & 19.13 & 23.47 \\
\hline 32 & Conservation of environment & 28.57 & 37.50 & 55.36 \\
\hline 33 & Endangered wildlife & 3.57 & 8.93 & 5.36 \\
\hline 34 & Environmental Pollution & 1.79 & 0.00 & 1.79 \\
\hline 35 & Environmental Education & 12.50 & 19.64 & 17.86 \\
\hline 36 & Environmental Products/Process related & 32.14 & 41.07 & 44.64 \\
\hline 37 & Environmental Audit/Independent Verification Statement & 0.00 & 1.79 & 1.79 \\
\hline 38 & Environmental Management System/Policy & 28.57 & 25.00 & 37.50 \\
\hline $\mathbf{F}$ & Corporate Governance Theme & 22.14 & 21.79 & 21.43 \\
\hline 39 & Shariah compliance status & 3.57 & 3.57 & 3.57 \\
\hline 40 & Ownership structure: Number of muslim shareholders and its shareholdings & 0.00 & 0.00 & 0.00 \\
\hline 41 & BOD structure-muslim vs non-muslim members & 100.00 & 100.00 & 100.00 \\
\hline 42 & $\begin{array}{l}\text { Declaration of forbidden activities: monopolistic practice/hoarding necessary } \\
\text { goods/price manipulation/fraudulent business practice/gambling }\end{array}$ & 3.57 & 3.57 & 1.79 \\
\hline 43 & Anti-corruption policies & 3.57 & 1.79 & 1.79 \\
\hline
\end{tabular}




\section{KEY FINDINGS}

There were two ISR items that were frequently disclosed by all the corporations over the three year period, viz., riba activities and BOD structure between Muslims and non-Muslims. The riba activities were reported as 'interest income' or 'interest expense', while the information on BOD structure disclosure was required by law. It was hoped that these two items would be disclosed directly and clearly in all future annual reports of companies under ISR.

This study also found six Islamic information that were not disclosed, namely; gharar, policy on late repayments and insolvent clients, CVBS, higher echelons in the company performed the congregational prayers with lower and middle level managers, Muslim employees were allowed to perform their obligatory prayers during specific times and fasting during Ramadhan on their working day and finally the number of Muslim shareholders and its shareholdings.

Examples of key findings included; VAS was disclosed in the annual report of some corporations such as IJM Corporation Bhd and Petroleum Gas Bhd in all the three years. However, this did not comply with the proposed VAS as suggested by Baydoun and Willet (2000). Another example of disclosure in a shariah-approved company was the Lion Industries Corporation Bhd, which disclosed that they were involved in the brewery business in all the three years. These were forbidden activities according to shariah.

Another key finding was that Society was the highest theme of disclosure for all the three years. This showed that corporations were well aware of their corporate social responsibility and the involvement of companies with society was a key part of ISR. The Finance and Investment theme displayed the lowest theme of disclosure for 2005 and 2006. This was indicative of a lack of transparency in terms of disclosure with respect to Islamic values especially for two important ISR items, namely CVBS and VAS. The CVBS was important for the accurate computation of zakat while the VAS would show how the benefits of the company were shared among the employees, shareholders, government, the company itself and also whether the companies dealt with insolvent clients ethically.

\section{CONCLUSION}

The main objective of this study was to examine the extent of Islamic Social Reporting in the annual reports by shariah-approved companies listed in Bursa Malaysia. Based on the descriptive statistics of the disclosure index, it could be concluded that the extent of ISR was considered minimal, thus indicating a lack of transparency in the disclosure with respect to Islamic values despite the fact that the concept of social accountability under Islam is related to the principle of full disclosure. This is especially the case with CVBS and VAS - two important ISR items linked to zakat - and the sharing of company benefits among stakeholders. Hence, the objectives of social justice, equitability and maintenance of welfare, which are the primary characteristics of a Muslim society, will continue remaining as a dream.

Malaysia, being a model of modern Islam, had been experiencing pressure to embrace internationally accepted corporate governance best practices. This pressure was evident with the amendment by the Bursa Malaysia's Listing Rules that required publicly listed companies to disclose a narrative of how they had applied the principles of corporate governance and the extent of its compliance with the Code on Corporate Governance' best practices. All these should lead to better transparency and accountability, as required by Islam.

\section{FUTURE RESEARCH}

This study had focused on annual reports to measure the extent of the ISR disclosure practices by the selected companies. Future research could be extended to include other forms of disclosure such as interim reports, press releases, stock market announcements and internet financial reporting. The interpretation of some ISR items in the coding process was subjective. A better method could be improvised for a more objective rating and evaluation. 
Last but not least, this study had contributed a new dimension of corporate reporting to the policy makers, practitioners, researchers and the Muslim stakeholders. Perhaps ISR could be a bridge between the world and the hereafter that raises the level of human consciousness on worldly activities that were related with their destiny in the hereafter.

\section{AUTHOR INFORMATION}

Dr Rohana Othman is an Associate Professor in Accounting at Universiti Teknologi MARA, Malaysia. She is a lecturer at the Faculty of Accountancy specializing in the areas of public sector accountability and accounting and forensic accounting. She receives her $\mathrm{Ph} \mathrm{D}$ in Accounting degree from the International Islamic University Malaysia, Kuala Lumpur. She also holds a Bsc in Accounting from Indiana State University, USA and a Master in Business Administration (specializing in Accounting) from University of Hartford, Connecticut, USA. Her current research interests include Public Sector Accountability and Governance, Islamic Accounting and Reporting, Management Control System, Forensic Accounting, Corporate Governance and Corporate Social Responsibility.

Azlan Md Thani is a lecturer of Accounting, Universiti Teknologi MARA, Pahang. He holds Master of Accountancy degree from Universiti Teknologi MARA, Malaysia. He is an associate member of the Malaysian Institute of Accountants. His area of interests is in Islamic Accounting and Reporting, Taxation and Accounting for Zakat.

\section{REFERENCES}

1. ACCA, (2003), "Environmental Reporting Guidelines for Malaysian Companies".

2. ACCA, (2005), "Sustainability Reporting Guidelines for Malaysian Companies".

3. Baydoun, N. and Willet, R., (1997), "Islam and Accounting: Ethical Issues in the Presentation of Financial Information", Accounting, Commerce and Finance: The Islamic Perspective, Vol. 1 No. 1, pp.1-25

4. Baydoun, N. and Willet, R., (2000), "Islamic Corporate Reports", ABACUS, Vol. 36 No.1, pp. 71-90

5. Bukhari. Shahih Al-Bukhari, http://www.sahihalbukhari.com/

6. Bursa Malaysia, (2007), http://www.bursamalaysia.com, accessed on June 2007

7. Bursa Malaysia, "The Islamic Capital Market"

8. Bursa Malaysia. 2001. Listing requirements for main board and second board. Kuala Lumpur: Bursa Malaysia. Available at http://www.bursamalaysia.com

9. Bursa Malaysia. 2007. The Islamic Capital Market. Kuala Lumpur: Bursa Malaysia. Available at http://www.bursamalaysia.com

10. Global Reporting Initiative, "GRI Sustainability Reporting Guidelines-Reference Sheet"

11. Gray, R., Kouhy, R. and Lavers, S., (1995), "Corporate social and environmental reporting: a review of the literature and a longitudinal study of UK disclosure", Accounting, Auditing and Accountability Journal, Vol. 8 No. 2, pp.47-77

12. Guthrie, J., Petty, R. and Ricceri, F., (2006), “The voluntary reporting of intellectual capital”, Journal of Intellectual Capital, Vol. 7 No. 2, pp. 254-271

13. Haniffa, R. and Hudaib, M.A., (2002), “A theoretical framework for the development of the Islamic perspective of accounting", Accounting, Commerce \& Finance: The Islamic Perspective Journal, Vol. 6 No. $1 \& 2$, pp. 1-71

14. Haniffa, R., (2002), "Social Reporting Disclosure-An Islamic Perspective", Indonesian Management \& Accounting Research Vol.1 No.2, pp.128-146

15. Haniffa, R.M. and Hudaib, M.A. (2001), “A Conceptual Framework for Islamic Accounting: The Shari’a Paradigm", paper presented at the Accounting, Commerce \& Finance: The Islamic Perspective International Conference IV, New Zealand

16. Harahap, S.S., (2003), "The Disclosure of Islamic Values-Annual Report: The Analysis of Bank Muamalat Indonesia's Annual Report”, Managerial Finance, Vol. 29 No. 7: pp. 70-89

17. Hassan, S., (2006), "Corporate Governance Practices of Shariah Islamiah Approved and Shariah Islamiah Non-Approved Companies: Does it matter?”, Paper presented at IIUM International Accounting Conference 3, 26-28 June 2006, Kuala Lumpur, Malaysia 
18. Maali, B., Casson, P. and Napier, C., (2006), "Social Reporting by Islamic Banks", ABACUS, Vol. 42 No. 2, pp: 266-289

19. Malaysia. 1965. Company Act 1965

20. Malaysia. 1997. Financial Reporting Act 1997

21. Malaysia. 2006. Financial Reporting Standards 2000

22. Malaysia. Malaysian Accounting Standards Board (1999)

23. Malaysia. Malaysian Code of Corporate Governance Revised 2007

24. MASB Technical Release $i$-1: Accounting for zakat on business, (2006).

25. Mohamed Zain, M., (1999), "Corporate Social Reporting in Malaysia: The Current State of the art and Future Prospects", Dissertation for the Degree of Doctor of Philosophy, University of Sheffield

26. Muhammad, A., (2006), "Financial Report: From the Islamic Perspective-Case Study of Puncak Niaga", Work Paper, pp.1-14

27. Nik Ahmad, N.N., Sulaiman, M. and Siswantoro, D., (2003), "Corporate Social Responsibility Disclosure in Malaysia: An Analysis of Annual Reports of KLSE Listed Companies", IIUM Journal of Economics and Management 11, No. 1, pp. 1-37

28. Ousama,A.A. and Fatima, A.H., (2006), "The Determinants of Voluntary Disclosure in the Annual Reports by Shariah Approved Companies Listed on Bursa Malaysia", Paper presented at IIUM International Accounting Conference 3, 26-28 June 2006, Kuala Lumpur, Malaysia

29. Siddiqi, M.N., (1981), "Muslim Economic Thinking: A survey of contemporary literature", The Islamic Foundation, United Kingdom

30. Sulaiman, M. and Willet, R., (2003), "Using the Hofstede-Gray framework to argue normatively for an extension of Islamic Corporate Reports", Malaysian Accounting Review, Vol. 2 No. 1, pp. 1-39

31. Sulaiman, M., (2005), "Islamic Corporate Reporting: Between the Desirable and the Desired", Research Centre IIUM Publication

32. Thompson, P. and Zakaria, Z., (2004), "Corporate Social Responsibility Reporting in Malaysia-Progress and Prospects", Journal of Corporate Citizenship 13, pp. 125-136

33. Zulkifli, N. and Amran, A., (2006), "Realising Corporate Social Responsibility in Malaysia-A view from the Accounting Profession", Journal of Corporate Citizenship 24, pp. 101-114 


\section{APPENDIX A}

The Disclosure Index Coding Sheet

Company name:.

Industry:

\begin{tabular}{|c|c|c|c|c|}
\hline & & 2004 & 2005 & 2006 \\
\hline & Islamic Social Reporting (ISR): & & & \\
\hline A & Finance And Investment & & & \\
\hline 1 & Riba activities & & & \\
\hline 2 & Gharar & & & \\
\hline 3 & $\begin{aligned} & \text { Zakat: } \\
&- \text { method used } \\
&- \text { zakatable amount } \\
&- \text { beneficiaries } \\
&\end{aligned}$ & & & \\
\hline 4 & Late Repayments and Insolvent Clients/Bad Debts written-off & & & \\
\hline 5 & Current Value Balance Sheet (CVBS) & & & \\
\hline 6 & Value Added Statement (VAS) & & & \\
\hline B & Products And Services & & & \\
\hline 7 & Green product & & & \\
\hline 8 & Halal status of the product & & & \\
\hline 9 & Product safety and quality & & & \\
\hline 10 & $\begin{array}{l}\text { Customer complaints/incidents of non-compliance with regulation and voluntary codes } \\
\text { (if any) }\end{array}$ & & & \\
\hline $\mathbf{C}$ & Employees & & & \\
\hline 11 & $\begin{array}{l}\text { Nature of work: } \\
\text {-working hours } \\
\text {-holidays } \\
\text {-other benefits }\end{array}$ & & & \\
\hline 12 & Education and Training/Human Capital Development & & & \\
\hline 13 & Equal Opportunities & & & \\
\hline 14 & Employee involvement & & & \\
\hline 15 & Health and Safety & & & \\
\hline 16 & Working environment & & & \\
\hline 17 & $\begin{array}{l}\text { Employment of other special-interest-group (i.e. handicapped, ex-convicts, former } \\
\text { drug-addicts) }\end{array}$ & & & \\
\hline 18 & $\begin{array}{l}\text { Higher echelons in the company perform the congregational prayers with lower and } \\
\text { middle level managers. }\end{array}$ & & & \\
\hline 19 & $\begin{array}{l}\text { Muslim employees are allowed to perform their obligatory prayers during specific } \\
\text { times and fasting during Ramadhan on their working day. }\end{array}$ & & & \\
\hline 20 & Proper place of worship for the employees. & & & \\
\hline D & Society & & & \\
\hline 21 & Saddaqa/Donation & & & \\
\hline 22 & Waqf & & & \\
\hline 23 & QardHassan & & & \\
\hline 24 & Employee Volunteerism & & & \\
\hline 25 & $\begin{array}{l}\text { Education-School Adoption Scheme } \\
\text { - Scholarships }\end{array}$ & & & \\
\hline 26 & Graduate employment & & & \\
\hline 27 & Youth development & & & \\
\hline 28 & Underprivileged community & & & \\
\hline 29 & Children care & & & \\
\hline 30 & Charities/Gifts/Social activities & & & \\
\hline 31 & Sponsoring public health/recreational project/sports/cultural events & & & \\
\hline
\end{tabular}




\begin{tabular}{|c|c|c|c|c|}
\hline & & 2004 & 2005 & 2006 \\
\hline $\mathbf{E}$ & Environment & & & \\
\hline 32 & Conservation of environment & & & \\
\hline 33 & Endangered wildlife & & & \\
\hline 34 & Environmental Pollution & & & \\
\hline 35 & Environmental Education & & & \\
\hline 36 & Environmental Products/Process related & & & \\
\hline 37 & $\begin{array}{l}\text { Environmental Audit/ } \\
\text { Independent Verification Statement/Governance }\end{array}$ & & & \\
\hline 38 & Environmental Management System/Policy & & & \\
\hline $\mathbf{F}$ & Corporate Governance & & & \\
\hline 39 & Shariah compliance status & & & \\
\hline 40 & $\begin{array}{l}\text { Ownership structure: } \\
-\quad \text { Number of muslim shareholders and its shareholdings }\end{array}$ & & & \\
\hline 41 & Board structure-muslim vs non-muslim & & & \\
\hline 42 & 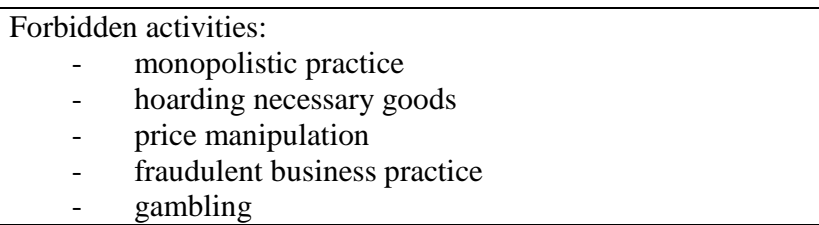 & & & \\
\hline 43 & Anti-corruption policies & & & \\
\hline
\end{tabular}

